\title{
“ANALISIS RASIO TERHADAP LIKUIDITAS, SOLVABILITAS, PROFITABILITAS TERHADAP KINERJA PERUSAHAAN YANG TERDAFTAR DI BURSA EFEK INDONESIA "
}

\author{
MAKASSAR
}

Lorensa

(lorensaencha@gmail.com)

Institut Bisnis dan Keuangan Nitro Makassar Jl. Prof Abdurahman Basalamah No. 101 90231

\begin{abstract}
Abstrak
ratio pada perusahaan yang terdaftar di Bursa Efek Indonesia. Dalam analisa fundamental, price earning ratio sering digunakan karena cukup mudah dipahami oleh investor maupun calon investor sebagai ukuran untuk menentukan bagaimana pasar memberi nilai/harga pada suatu perusahaan. Rasio keuangan yang digunakan yaitu rasio likuiditas, rasio solvabilitas, rasio aktivitas, dan rasio profitabilitas. Dalam penelitian ini variable yang ada adalah variable bebas yaitu current ratio(CR), debt to equity ratio(DER), inventory turnover (INTO), return on equity (ROE) dan variable terikat yaitu price earning ratio saham (PER). Jenis data yang digunakan adalah data sekunder dari setiap perusahaan PT. Semen Batu Raja (Persero) Tbk yang terdaftar di Bursa Efek Indonesia. Pengambilan sample dilakukan secara purposive random sampling. Hasil penelitian menunjukkan bahwa rasio likuiditas (current ratio), rasio aktivitas (inventory turnover), dan rasio profitabilitas (return on equity) mempunyai pengaruh yang signifikan terhadap price earning ratio saham perusahaan perusahaan pada PT. Semen Batu Raja (Persero) Tbk Sedangkan rasio solvabilitas (debt to equity ratio) mempunyai pengaruh yang Penelitian ini bertujuan untuk mengetahui pengaruh rasio keuangan terhadapa price earning tidak signifikan terhadap price earning ratio saham perusahaan manufaktur. Penelitian ini dapat digunakan sebagai acuan bagi para investor dalam memprediksi harga saham perusahaan yang akan datang dan dalam pengambilan keputusan untuk berinvestasi.

Kata kunci: Analisis rasio likuiditas,solvabilitas,profitabilitas,kinerja perusahaan.
\end{abstract}




\section{PENDAHULUAN}

\subsection{Latar Belakang}

Masalah keuangan merupakan salah satu masalah yang sangat vital bagi perusahaan dalam perkembangan bisnis di semua perusahaan. Salah satu tujuan utama didirikannya perusahaan adalah untuk memperoleh keuntungan yang maksimal. Berhasil tidaknya perusahaan dalam mencari keuntungan dan mempertahankan perusahaannya tergantung pada manajemen keuangan. Perusahaan harus memiliki kinerja keuangan yang sehat dan efisien untuk mendapatkan keutungan atau laba. Oleh sebab itu, kinerja keuangan merupakan hal yang penting bagi setiap perusahaan di dalam persaingan bisnis untuk mempertahankan perusahaannya.

Penilaian kerja keuangan suatu perusahaan merupakan salah satu cara yang dapat dilakukan oleh manajemen agar dapat memenuhi kewajibannya terhadap para penyandang dana dan untuk mencapai tujuan yang telah ditetapkan perusahaan. Penilaian kinerja perusahaan yang ditimbulkan sebagai akibat dari proses pengambilan keputusan manajemen merupakan persoalan yang kompleks karena menyangkut efektivitas pemanfaatan modal dan efisiensi dari kegiatan perusahaan yang menyangkut nilai serta keamanan dari berbagai tuntutan yang timbul terhadap perusahaan dalam menilai dan mengukur kinerja keuangan harus diimbangi dengan perencanaan keuangan yang baik.

Suatu badan usaha pasti mengharapkan agar kegiatan operasionalnya dapat berjalan dengan baik dan terus berlangsung sepanjang masa. Akan tetapi dengan keadaan yang selalu berubah, maka stabilitas keuangan tertentu tidak bisa dicapai sepanjang masa. Oleh karena itu, pemilik dan pengelola bisnis perlu mempertimbangkan untuk mengembangkan atau memperluas usaha dengan memperhatikan perkembangan perekonomian, peningkatan persaingan dan keinginan untuk membangun keunggulan kompetitif jangka panjang.

Perkembangan yang terjadi di bidang keuangan akan mempengaruhi berbagai aspek yang berkaitan dengan kesehatan suatu perusahaan. Dengan kondisi tersebut, maka perlu dilakukan penyempurnaan tata cara penilaian tingkat kesehatan suatu 
perusahaan, sehingga kebenaran dalam perhitungan tingkat kesehatan mutlak menjadi tanggung jawab perusahaan sepenuhnya yang tentunya di dukung oleh sistem pelaporan yang akurat, tepat dan benar. Untuk menilai kesehatan suatu perusahaan, maka diciptakan rambu-rambu oleh pihak pemerintah yang tentunya ada maksud dan tujuannya yang sangat membantu para pengelola suatu perusahaan untuk mengetahui secara dini atas kesehatan perusahaan masing-masing.

Sebagai pemilik perusahaan ataupun pihak yang berkepentingan, tentu ingin pula mengetahui perkembangan perusahaan dari hasil kegiatan usahanya dari waktu ke waktu. Oleh karena itu, menilai kondisi keuangan suatu perusahaan merupakan suatu hal yang sangat penting karena dapat digunakan sebagai alat penilaian kinerja keuangan kedepannya. Perusahaan didirikan dalam jangka waktu panjang untuk meningkatkan laba, sehingga harus mampu mempertinggi rasio laba. Jadi perusahaan harus diarahkan ke titik profitabilitas yang maksimal sehingga kinerja perusahaan akan membaik. Untuk mengetahui kondisi keuangan perusahaan, maka perlu dilakukan pengukuran kinerja keuangan perusahaan agar dapat mengetahui keadaan keuangan perusahaan.

Pengukuran kinerja perusahaan yang sering dipakai adalah menganalisis laporan keuangan menggunakan rasio. Pada penelitian ini, analisis dilakukan dengan menggunakan rasio likuiditas, rasio solvabilitas dan rasio profitabilitas. Rasio likuiditas digunakan untuk menunjukkan kemampuan perusahaan dalam memenuhi liabilitas jangka pendeknya. Rasio solvabilitas digunakan untuk mengukur sejauhmana aktiva perusahaan didanai oleh utang. Rasio profitabilitas menggambarkan kemampuan perusahaan untuk menghasilkan keuntungan.

Obyek penelitian yang digunakan adalah salah perusahaan yang terdaftar di Bursa Efek Indonesia yaitu perusahaan industri yang bergerak di bidang industri semen. Pertumbuhan industri semen dari tahun ke tahun semakin meningkat. Berdasarkan penjualan, tercacat pertumbuhan industri semen mulai dari tahun 2016 dengan volume penjualan mencapai 66,35 juta ton dan pertumbuhan sebanyak $1,70 \%$. Pada tahun 2017, penjualan mencapai 69,4 juta ton dengan pertumbuhan $9,7 \%$. Tahun 2018 , volume penjualan mencapai 75,2 juta ton dengan pertumbuhan $8,4 \%$. Kemudian pada 
tahun 2019, penjualan semen mencapai 76,1 juta ton dengan pertumbuhan $1,2 \%$ (www.kemenperin.go.id / www.cnbcindonesia.com).

PT. Semen Batu Raja (Persero) Tbk merupakan salah satu perusahaan yang terkemuka di Indonesia yang didirikan pada 14 November 1974. Perusahaan ini lahir dengan nama PT. Semen Baturaja (Persero) dengan kepemilikan saham sebesar $45 \%$ yang dimiliki oleh PT. Semen Gresik dan PT. Semen Padang sebesar 55\%. Lima tahun kemudian, pada tanggal 9 November 1979, perusahaan berubah status dari Penanaman Modal Dalam Negeri (PMDM) menjadi Persero dengan komposisi saham sebesar $88 \%$ dimiliki oleh Pemerintah Republik Indonesia, PT Semen Padang sebesar 7\% dan PT Semen Gresik sebesar 5\%. Beberapa tahun kemudian yaitu pada tahun 1991, saham perseroan diambil alih secara penuh oleh Pemerintah Republik Indonesia. Selanjutnya perseroan terus mengalami perkembangan sehingga pada tanggal 14 Maret 2013, PT. Semen Baturaja (Persero) mengalami perubahan status menjadi Perseroan terbuka dan berubah nama menjadi PT Semen Baturaja (Persero) Tbk.

Berdasarkan segi aset, perusahaan tersebut mengalami peningkatan dari tahun ke tahun. Namun dari pembukuan laba bersih yang tercatat, perusahaan mengalami penurunan dari tahun 2016 hingga 2019 dengan nilai tiap tahunnya sebanyak 146,6 M ditahun 2017, lebih banyak dari tahun sebelumnya yaitu 259 M. Sedangkan untuk tahun 2019, perusahaan memperoleh laba bersih senilai $30 \mathrm{M}$, lebih banyak dari tahun sebelumnya yaitu 2017 dengan nilai laba yang diperoleh $76 \mathrm{M}$. Melihat perbedaan dan penurunan kinerja keuangan pada perusahaan ini, kami terdorong untuk menganalisis kinerja PT. Semen Batu Raja (Persero) Tbk berdasarkan analisis rasio likuiditas, solvabilitas dan profitabilitas pada periode 2016 hingga 2019.

Berdasarkan penjelasan latar belakang diatas maka penulis tertarik untuk melakukan penelitian mengenai "ANALISIS RASIO TERHADAP LIKUIDITAS, SOLVABILITAS, PROFITABILITAS TERHADAP KINERJA PERUSAHAAN YANG TERDAFTAR DI BURSA EFEK INDONESIA " 


\section{Rumusan Masalah}

Berdasarkan uraian dalam latar belakang di atas, maka rumusan masalah dalam penelitian ini adalah "Bagaimana kinerja PT. Semen Batu Raja (Persero) Tbk berdasarkan analisis rasio likuiditas, solvabilitas dan profitabilitas pada periode 20162019?"

Tujuan Dan Kegunaan Penelitian

Berdasarkan rumusan masalah di atas, maka tujuan dalam penelitian ini sebagai berikut:

1.Mengetahui kinerja perusahaan pada PT. Semen Batu Raja (Persero) Tbk dilihat dari rasio likuiditas.

2.Mengetahui kinerja perusahaan pada PT. Semen Batu Raja (Persero) Tbk dilihat dari rasio solvabilitas.

3.Mengetahui kinerja perusahaan pada PT. Semen Batu Raja (Persero) Tbk dilihat dari rasio profitabilitas.

4.Sebagai acuan bisnis atau mitra kerja dalam menanggapi kondisi atau posisi keuangan perusahaan pada PT. Semen Batu Raja (Persero) Tbk berdasarkan analisis rasio likuiditas, solvabilitas dan profitabilitas.

\section{TINJAUAN PUSTAKA}

\subsection{Kinerja Perusahaan}

\subsubsection{Pengertian Kinerja Perusahaan}

Perusahaan sebagai salah satu bentuk organisasi pada umumnya memiliki tujuan tertentu yang ingin dicapai dalam usaha untuk memenuhi kepentingan para anggotanya. Keberhasilan dalam mencapai tujuan perusahaan merupakan prestasi manajemen. Penilaian prestasi atau kinerja suatu perusahaan diukur karena dapat dipakai sebagai dasar pengambilan keputusan baik pihak internal maupun eksternal.

Kinerja perusahaan merupakan suatu gambaran tentang kondisi keuangan suatu perusahaan yang dianalisis dengan alat-alat analisis keuangan, sehingga dapat diketahui mengenai baik buruknya keadaan keuangan suatu perusahaan yang 
mencerminkan prestasi kerja dalam periode tertentu. Hal ini sangat penting agar sumber daya digunakan secara optimal dalam menghadapi perubahan lingkungan.

Penilaian kinerja keuangan merupakan salah satu cara yang dapat dilakukan oleh pihak manajemen agar dapat memenuhi kewajibannya terhadap para penyandang dana dan juga untuk mencapai tujuan yang telah ditetapkan oleh perusahaan. Sebelum memahami masalah penilaian kinerja lebih jauh, maka ada beberapa pengertian kinerja. Menurut Helfert (1996: 67), "kinerja perusahaan adalah hasil dari banyak keputusan individual yang dibuat secara terus menerus oleh manajemen."

Berdasarkan pendapat tersebut, maka dapat diketahui bahwa kinerja merupakan indikator dari baik buruknya keputusan manajemen dalam pengambilan keputusan. Manajemen dapat berinteraksi dengan lingkungan interen maupun eksteren melalui informasi. Informasi tersebut lebih lanjut dituangkan atau dirangkum dalam laporan keuangan perusahaan.

Pengertian lain tentang kinerja menurut Stoner, et al. (1996: 9) yaitu "performance yaitu ukuran seberapa efisien dan efektif sebuah organisasi atau seorang manajer untuk mencapai tujuan yang memadai." Adapun pengertian efektif dan efisien menurut Stoner, et. al (1996:9) ialah "efisien adalah kemampuan untuk meminimalkan penggunaan sumber daya dalam mencapai tujuan organisasi berarti melakukan dengan tepat, sedangkan efektivitas adalah kemampuan untuk menentukan tujuan yang memadai berarti melakukan hal yang tepat."

Berdasarkan pengertian di atas, maka dapat disimpulkan bahwa kinerja (performance) perusahaan adalah hasil dari banyak keputusan yang dibuat secara terus menerus oleh manajemen untuk mencapai tujuan tertentu secara efektif dan efisien.

\subsubsection{Manfaat Penilaian Kinerja Perusahaan}

Adapun manfaat dari penilaian kinerja perusahaan adalah sebagai berikut ;

1. Untuk mengukur prestasi yang dicapai oleh suatu organisasi dalam suatu periode tertentu yang mencerminkan tingkat keberhasilan pelaksanaan kegiatannya. 
2. Selain digunakan untuk melihat kinerja organisasi secara keseluruhan, maka pengukuran kinerja juga dapat digunakan untuk menilai kontribusi suatu bagian dalam pencapaian tujuan perusahaan secara keseluruhan.

3. Dapat digunakan sebagai dasar penentuan strategi perusahaan untuk masa yang akan datang.

4. Memberi petunjuk dalam pembuatan keputusan dan kegiatan organisasi pada umumnya dan divisi atau bagian organisasi pada khususnya.

5. Sebagai dasar penentuan kebijaksanaan penanaman modal agar dapat meningkatkan efisiensi dan produktivitas perusahaan.

\subsubsection{Tujuan Penilaian Kinerja Perusahaan}

Tujuan penilaian kinerja perusahaan menurut Munawir (2000:31) adalah sebagai berikut ;

1. Untuk mengetahui tingkat likuiditas, yaitu kemampuan perusahaan untuk memperoleh kewajiban keuangannya yang harus segera dipenuhi atau kemampuan perusahaan untuk memenuhi keuangannya pada saat ditagih.

2. Untuk mengetahui tingkat solvabilitas, yaitu kemampuan perusahaan untuk memenuhi kewajiban keuangannya apabila perusahaan tersebut dilikuidasi baik kewajiban keuangan jangka pendek maupun jangka panjang.

3. Untuk mengetahui tingkat rentabilitas atau profitabilitas, yaitu menunjukkan kemampuan perusahaan untuk menghasilkan laba selama periode tertentu.

4. Untuk mengetahui tingkat stabilitas usaha, yaitu kemampuan perusahaan untuk melakukan usahanya dengan stabil, yang diukur dengan mempertimbangkan kemampuan perusahaan untuk membayar beban bunga atas hutang-hutangnya termasuk membayar kembali pokok hutangnya tepat pada waktunya serta kemampuan membayar deviden secara teratur kepada para pemegang saham tanpa mengalami hambatan atau krisis keuangan.

\subsection{Kinerja Keuangan Perusahaan}

\subsubsection{Pengertian Kinerja Keuangan}


Pengertian kinerja menurut Simamora (2002) adalah suatu pencapaian pekerjaan tertentu yang akhirnya secara langsung dapat tercermin dari keluaran yang dihasilkan baik jumlah maupun kualitasnya. Sedangkan kinerja menurut Salim (1991:190) adalah "prestasi kerja yang merupakan hasil kerja yang diperoleh dari melaksanakan tugas yang dibebankan kepada seseorang".

Kinerja merupakan kondisi yang harus diketahui dan diinformasikan kepada pihakpihak tertentu untuk mengetahui tingkat pencapaian hasil suatu instansi dihubungkan dengan misi yang diemban suatu organisasi serta mengetahui dampak postif atau negatif suatu kewajiban operasional yang diambil. Dengan adanya informasi mengenai kinerja perusahaan, akan dapat diambil tindakan yang diperlukan seperti koreksi atau kebijakan, meluruskan kegiatan-kegiatan utama dan tugas pokok perusahaan, bahan untuk perencanaan, menentukan tingkat keberhasilan perusahaan untuk memutuskan suatu kebijaksanaan dan lainnya.

Disimpulkan bahwa kinerja keuangan perusahaan adalah gambaran hasil dari banyak keputusan yang dibuat secara terus-menerus oleh manajemen untuk mencapai tujuan tertentu secara efektif dan efisien serta untuk melihat kemampuan atau prestasi yang dicapai dalam melaksanakan suatu kegiatan tertentu dalam kurun waktu tertentu.

Menurut Sugiono dan Untung (2016: 54) dari segi manajemen keuangan, perusahaan dikatakan mempunyai kinerja yang baik atau tidak, dapat diukur dengan hal berikut ;

a. Kemampuan perusahaan untuk memenuhi kewajiban (Hutang) yang akan jatuh tempo (liquidity).

b. Kemampuan perusahaan untuk menyusun struktur pendanaan yaitu perbandingan antara hutang dan modal (leverange).

c. Kemampuan perusahaan memperoleh keuntungan (profitability).

d. Kemampuan perusahaan untuk mengelola asset secara maksimal (activity).

\subsubsection{Tujuan Pengukuran Kinerja Keuangan}

Menurut Munawir (2012:31) menyatakan bahwa tujuan dan pengukuran kinerja keuangan perusahaan adalah; 
1. Mengetahui tingkat likuiditas. Likuiditas menunjukkan kemampuan suatu perusahaan untuk memenuhi kewajiban keuangan yang harus segera diselesaikan pada saat ditagih.

2. Mengetahui tingkat solvabilitas. Solvabilitas menunjukkan kemampuan perusahaan untuk memenuhi kewajiban keuangannya apabila perusahaan tersebut dilikuidasi, baik keuangan jangka pendek maupun jangka panjang.

3. Mengetahui tingkat profitabilitas. Profitabilitas atau biasa juga disebut rentabilitas menunjukkan kemampuan perusahaan untuk menghasilkan laba selama periode tertentu.

4. Mengetahui tingkat stabilitas. Stabilitas menunjukkan kemampuan perusahaan untuk melakukan usahanya dengan stabil, yang diukur dengan mempertimbangkan kemampuan perusahaan untuk membayar hutang-hutangnya serta membayar beban bunga atas hutang-hutangnya tepat pada waktunya.

\subsection{Laporan Keuangan}

\subsubsection{Pengertian Laporan Keuangan}

Laporan keuangan dalam praktiknya oleh perusahaan harus dibuat dan disusun sesuai dengan aturan atau standar yang berlaku. Laporan keuangan yang disajikan perusahaan sangat penting bagi manajemen dan pemilik perusahaan. Di samping itu, banyak pihak yang memerlukan dan berkepentingan terhadap laporan keuangan yang dibuat perusahaan, seperti pemerintah, kreditor, investor, maupun para supplier.

Laporan keuangan menurut Kasmir (2016: 6) adalah "laporan yang menujukkan kondisi keuangan perusahaan pada saat ini atau dalam suatu periode tertentu." Sementara menurut Standar Akuntansi Keuangan (SAK) pada ruang lingkup laporan keuangan (2015:1) adalah "laporan keuangan bagian dari proses pelaporan keuangan yang lengkap biasanya meliputi neraca, laporan laba rugi, laporan perubahan posisi keuangan (yang dapat disajikan dalam berbagai cara, sebagai contoh, sebagai laporan arus kas, atau laporan arus dana, catatan dan laporan lain serta materi penjelasan yang merupakan bagian integral dari laporan keuangan." Di samping itu pula termasuk skedul dan informasi tambahan yang berkaitan dengan laporan tersebut, sebagai 
contoh informasi keuangan segmen industri dan geografis serta perangkapan pengaruh perubahan harga.

\subsubsection{Jenis Laporan Keuangan}

1. Laporan laba rugi adalah suatu laporan keuangan yang di dalamnya menjelaskan tentang kinerja keuangan suatu entitas bisnis dalam satu periode akuntansi, di dalamnya terdapat informasi ringkas mengenai jumlah biaya yang dikeluarkan untuk operasional suatu perusahaan serta laba yang didapatkan selama perusahaan tersebut beroperasi.

2. Neraca adalah salah satu bagian dari laporan keuangan suatu entitas bisnis / perusahaan yang di dalamnya terdapat informasi mengenai aktiva, kewajiban, serta ekuitas pemegam saham pada akhir periode akuntansi perusahaan tersebut.

3. Laporan perubahan modal adalah laporan keuangan yang menyajikan informasi mengenai perubahan modal pada perusahaan akibat dari kegiatan pokok operasi perusahaan pada suatu periode akuntansi tertentu. Atau dapat diartikan sebagai suatu ikhtisar tentang perubahan jumlah modal yang terjadi selama periode tertentu.

4. Laporan arus kas adalah laporan keuangan yang menyajikan informasi tentang penerimaan dan pengeluaran kas suatu perusahaan selama satu periode. Hal yang bisa disajikan atau digambarkan dalam laporan keuangan arus kas meliputi jumlah kas yang diterima, seperti pendapatan tunai dan investasi tunai dari pemilik serta jumlah kas yang dikeluarkan perusahaan, seperti beban-beban yang harus dikeluarkan, pembayaran utang dan pengembalian prive.

5. Laporan catatan atas laporan keuangan, adalah laporan yang dibuat berkaitan dengan laporan keuangan yang disajikan.

\subsubsection{Tujuan Laporan Keuangan}

Beberapa tujuan pembuatan atau penyusunan laporan keuangan menurut Kasmir (2016: 11), yaitu:

1. Memberikan informasi tentang jenis dan jumlah aktiva (harta) yang dimiliki perusahaan pada saat ini. 
2. Memberikan informasi tentang jenis dan jumlah kewajiban dan modal yang dimilik perusahaan saat ini.

3. Memberikan informasi tentang jumlah biaya dan jenis biaya yang dikeluarkan perusahaan dalam suatu periode tertentu.

4. Memberikan informasi terhadap perubahan-perubahan yang terjadi terhadap aktiva, pasiva dan modal perusahaan.

5. Memberikan informasi tentang kinerja manajemen perusahaan dalam suatu periode.

\subsubsection{Pihak-pihak yang Memerlukan Laporan Keuangan}

Berikut ini adalah masing-masing pihak yang berkepentingan terhadap laporan keuangan menurut Kasmir (2016: 19-23), yaitu:

1. Pemilik

Pemilik pada saat ini adalah mereka yang memiliki usaha tersebut. Hal ini tercermin dari kepemilikan saham yang dimilikinya. Kepentingan bagi para pemegang saham yang merupakan pemilik perusahaan terhadap hasil laporan keuangan yang telah dibuat adalah ;

a. Untuk melihat kondisi dan posisi perusahaan saat ini.

b. Untuk melihat perkembangan dan kemajuan perusahaan dalam suatu periode.

c. Untuk menilai kinerja manajemen atas target yang telah ditetapkan.

2. Manajemen

Kepentingan pihak manajemen perusahaan terhadap laporan keuangan perusahaan yang mereka juga buat memiliki arti tertentu. Berikut ini nilai penting laporan keuangan keuangan bagi manajemen ;

a. Dengan laporan keuangan yang dibuat, manajemen dapat dinilai dan mengevaluasi kinerja mereka dalam suatu periode.

b. Manajemen juga akan melihat kemampuan mereka mengoptimalkan sumber daya yang dimiliki perusahaan yang ada selama ini.

c. Laporan keuangan dapat digunakan untuk melihat kekuatan dan kelemahan yang dimiliki perusahaan saat ini.

d. Laporan keuangan dapat digunakan untuk mengambil keputusan keuangan kedepan berdasarkan kekuatan dan kelemahan yang dimiliki perusahaan, baik 
dalam hal perencanaan, pengawasan dan pengendalian kedepan sehingga targettarget yang diinginkan dapat tercapai.

3. Kreditor

Kreditor adalah pihak yang penyandang dana bagi perusahaan. Artinya pihak pemberi dana seperti bank atau lembaga keuangan lainnya. Kepentingan pihak kreditor antara lain sebagai berikut ;

a. Pihak kreditor tidak ingin usaha yang dibiayainya mengalami kegagal dalam hal pembayaran kembali pinjaman tersebut.

b. Pihak kreditor juga perlu memantau terhadap kredit yang sudah berjalan untuk melihat kepatuhan perusahaan membayar kewajibannya.

c. Pihak kreditor juga tidak ingin kredit atau pinjaman yang diberikan justru menjadi beban nasabah dalam pengembaliannya apabila ternyata kemampuan perusahaan di luar dari yang diperkirakan.

4. Arti penting laporan keuangan bagi pihak pemerintah adalah;

a. Untuk menilai kejujuran perusahaan dalam melaporkan seluruh keuangan perusahaan yang sesungguhnya.

b. Untuk mengetahui kewajiban perusahaan terhadap negara dan hasil laporan keuangan yang dilaporkan

5. Investor

Pihak yang hendak menanamkan dana di suatu perusahaan. Jika suatu perusahaan memerlukan dana untuk memperluas usaha atau kapasitas usahanya di samping memperoleh pinjaman dari lembaga keuangan seperti bank dapat pula diperoleh dari para investor melalui penjualan saham. Dalam memilih sumber dana pihak perusahaan memiliki berbagai pertimbangan tentunya seperti faktor bunga dan jumlah angsuran kedepan. Namun di sisi lain, perusahaan juga ingin memberikan peluang kepemilikan kepada masyarakat atau pihak lainnya.

\subsection{Analisis Laporan Keuangan}

\subsubsection{Pengertian Analisis Laporan Keuangan}

Analisis laporan keuangan melibatkan penggunaan laporan keuangan, terutama neraca dan laporan laba rugi karena laporang keuangan menyajikan informasi mengenai 
suatu perusahaan. Informasi kinerja terutama disediakan dalam laporan laba rugi. Analisis laporan keuangan menurut Wild dan Subramanyam (2005: 3) adalah "aplikasi dari alat dan teknik analisis untuk laporan keuangan bertujuan umum dan data-data yang berkaitan untuk menghasilkan estiminasi dan kesimpulan yang bermanfaat dalam analisis bisnis."

Laporan keuangan suatu perusahaan merupakan alat yang sangat penting untuk memperoleh informasi tentang kondisi keuangan perusahaan. Hal tersebut dikarenakan laporan keuangan merupakan bagian dari proses pelaporan keuangan. Lengkap keuangan yang lengkap biasanya meliputi neraca, laporan laba rugi, laporan perubahan posisi keuangan, catatan dan laporan lain serta materi penjelasan yang merupakan bagian integral yang dari laporan keuangan.

Pengertian analisis laporan keuangan menurut Standar Akuntansi Keuangan (2015:1) adalah suatu pengkajian terstruktur dari posisi keuangan dan kinerja keuangan suatu entitas. Tujuannya memberikan informasi mengenai posisi keuangan, kinerja keuangan, dan arus kas entitas yang bermanfaat bagi sebagian besar kalangan pengguna laporan dalam pemuatan keputusan investasi.

Berdasarkan beragam pendapat di atas,maka disimpulkan bahwa analisis laporan keuangan merupakan penelahan dari unsur-unsur laporan keuangan yang akan diubah menjadi unit informasi yang lebih kecil sehingga dapat diketahui kondisi keuangan, prospek dari usaha serta efektifitas manajemennya. Informasi tersebut sangat berguna bagi pihak manajemen untuk mengambil keputusan yang tepat bagi kelangsungan hidup perusahaan.

\subsubsection{Tujuan Analisis Laporan Keuangan}

Menurut Harahap (2009:195), tujuan analisis laporan keuangan adalah sebagai berikut ;

1. Dapat memberikan informasi yang lebih luas, lebih dalam daripada yang terdapat dari laporan keuangan biasa.

2. Dapat menggali informasi yang tidak tampak secara kasat mata dari suatu laporan keuangan atau yang berada di balik laporan keuangan.

3. Dapat mengatasi kesalahan yang terkandung di dalam laporan keuangan 
4. Dapat membongkar hal-hal yang bersifat tidak konsisten dalam hubungannya dengan suatu laporan keuangan baik dikaitkannya dengan informasi yang diperoleh dari luar perusahaan.

5. Mengetahui sifat-sifat hubungan yang akhirnya dapat melahirkan model-model dan teori-teori yang terdapat di lapangan seperti untuk di prediksi peningkatan.

6. Dapat memberikan informasi yang diinginkan oleh pengambil keputusan. Dengan perkataan lain apa yang dimaksud dari suatu laporan keuangan merupakan tujuan analisa laporan keuangan juga antara lain ;

a. Dapat menilai prestasi perusahaan.

b. Dapat memproyeksi keuangan perusahaan.

c. Dapat menilai kondisi keuangan masa lalu dan masa sekarang dari aspek waktu tertentu; Posisi keuangan (aset, neraca dan modal), hasil usaha perusahaan (hasil dan biaya), likiuiditas, solvabilitas, aktivitas, profitabilitas dan indikator pasar modal.

d. Menilai perkembangan dari waktu ke waktu.

e. Menilai komposisi struktur keuangan dan arus dana.

7. Dapat menentukan peringkat (rating) perusahaan menurut kriteria tertentu yang sudah dikenal dalam dunia bisnis

8. Dapat membandingkan situasi perusahaan dengan perusahaan lain dengan periode sebelumnya atau dengan standar industri normal atau standar ideal.

9. Dapat memahami situasi dan kondisi keuangan yang dialami perusahaan baik posisi keuangan, hasil usaha, struktur keuangan dan sebagainya.

Berdasarkan uraian di atas, maka dapat dinyatakan bahwa tujuan analisis laporan keuangan yang memberikan informasi yang lebih mendalam dari laporan keuangan terutama informasi yang diinginkan oleh pihak pengambil keputusan serta dapat digunakan sebagai alat untuk meramalkan kondisi keuangan perusahaan di masa yang akan datang.

\subsubsection{Metode dan Teknik Laporan Keuangan}

Metode dan teknik analisis laporan keuangan digunakan untuk menentukan dan mengukur hubungan antara pos-pos yang ada dalam laporan, sehingga dapat 
diketahui perubahan-perubahan dari masing-masing pos tersebut bisa diperbandingkan dengan laporan keuangan yang dibudgetkan atau dengan laporan keuangan perusahaan lainnya.

Menurut Prastowo dan Juliaty (2002: 54), secara umum metode analisis laporan keuangan dapat diklasifikasikan menjadi dua, yaitu ;

1. Metode Analisis Horizontal

Metode analisis horizontal adalah metode analisis yang dilakukan dengan cara membandingkan laporan keuangan untuk beberapa tahun, sehingga dapat diketahui perkembangan dan kecenderungannya. Disebut metode analisis horizontal karena analisis ini membandingkan pos yang sama untuk periode yang berbeda. Disebut metode yang dinamis karena metode ini bergerak dari tahun ke tahun. Teknik-teknik analisis yang termasuk pada klasifikasi metode ini antara lain, teknik analisis perbandingan, analisis trend, analisis sumber dan penggunaan dana serta analisis perubahan laba kotor.

2. Metode Analisis Vertikal

Metode analisis vertikal adalah metode analisis yang dilakukan dengan cara menganalisis laporan keuangan pada tahun (periode) tertentu, yaitu dengan membandingkan antara pos yang satu dengan pos yang lainnya pada laporan keuangan yang sama, maka disebut metode vertikal. Disebut metode statis karena metode ini hanya membanding-kan pos-pos laporan keuangan pada tahun yang sama. Teknik-teknik analisis yang termasuk pada klasifikasi metode ini antara lain, teknik analisis presentase per-komponen, analisis rasio dan analisis impas.

Teknik analisis laporan keuangan yang digunakan menurut Subramannyamet (2012:30) antara lain ;

1. Analisis laporan keuangan komperatif yang dilakukan dengan cara menelaah neraca, daftar laba rugi atau daftar arus kas yang berurutan dari satu periode ke periode berikutnya.

2. Analisis laporan keuangan common-size yaitu menyajikan laporan keuangan dalam bentuk persentese yang dikaitkan dengan suatu jumlah yang dinilai penting misalnya pos-pos neraca terhadap jumlah aktiva atau penjualan untuk laba rugi. 
3. Analisis rasio yaitu membandingkan antara pos-pos tertentu dengan pos lain yang memiliki hubungan ekonomis.

4. Analisis arus kas yaitu menggunakan daftar arus kas untuk melakukan evaluasi sumber dan penggunaan dana atau kas.

5. Penilaian yang biasanya didasarkan pada nilai intrinsik sebuah perusahaan atau sahamnya.

\subsection{Analisis Rasio Keuangan}

\subsubsection{Pengertian Analisis Rasio Keuangan}

Menurut Harvarindo (2010), rasio adalah satu angka yang dibanding-kan dengan angka lain sebagai suatu hubungan. Golin (2001) berpendapat bahwa rasio adalah suatu angka yang digambarkan dalam suatu pola yang dibandingkan dengan pola lainnya serta dinyatakan dalam persentase. Sedangkan keuangan adalah sesuatu yang berhubungan dengan akuntasi seperti pengelolaan keuangan dan laporan keuangan. Jadi rasio keuangan menurut Horne (Kasmir, 2016) adalah indeks yang menghubungkan dua angka akuntansi dan diperoleh dengan membagi satu angka dengan angka lainnya.

Setelah mengetahui pengertian rasio keuangan, analisis merupakan suatu usaha dalam mengamati secara detail pada suatu hal atau benda dengan cara menguraikan komponen-komponen pembentuknya atau menyusun komponen tersebut untuk dikaji lebih lanjut. Analisis juga dapat disebut sebagai proses untuk memecahkan sesuatu ke dalam bagian-bagian yang lebih dalam dan menyatu satu dengan yang lainnya.

Jadi, analisis rasio keuangan adalah proses pengamatan indeks yang berhubungan dengan akuntasi pada laporan keuangan seperti neraca, laporan laba rugi dan laporan arus kas dengan tujuan untuk menilai kinerja keuangan suatu perusahaan. Analisis ini digunakan untuk memberikan gambaran informasi mengenai posisi keuangan dan kinerja perusahaan yang dapat dijadikan sebagai pedoman dalam mengambil keputusan bisnis.

Analisis rasio keuangan digunakan oleh dua pengguna utama, yakni investor dan manajemen. Investor menggunakan rasio keuangan untuk melihat apakah perusahaan itu investasi yang bagus atau tidak. Dengan membandingkan rasio keuangan antar 
perusahaan dan antar industri, investor dapat menentukan investasi mana yang paling baik.

Pengertian analisis laporan keuangan menurut standar akuntansi keuangan dan kinerja keuangan suatu entitas. Tujuannya memberikan informasi mengenai posisi keuangan, kinerja keuangan dan arus kas entitas yang bermanfaat bagi sebagian besar kalangan penggunaan laporan keuangan dalam pembuatan keputusan investasi.

Sedangkan manajemen menggunakan rasio keuangan untuk menentukan seberapa baik kinerja perusahaan untuk mengevaluasi kemana perusahaan dapat memperbaiki diri. Misalnya, jika perusahaan memiliki margin kotor yang rendah, manajer dapat mengevaluasi bagaimana meningkatkan margin kotor mereka.

\subsubsection{Fungsi Analisis Rasio Keuangan}

Fungsi umum analisis rasio keuangan adalah bermanfaat untuk manajemen dan investor seperti yang telah disebutkan di atas. Tentu saja fungsi tersebut tidak sesederhana itu, berikut di antaranya ;

1. Berguna bagi seseorang/perusahaan yang ingin melakukan investasi pada saham.

2. Memberikan kredit kepada suatu perusahaan.

3. Menentukan tingkat kesehatan perusahaan supplier.

4. Menentukan tingkat kesehatan perusahaan customer/pelanggan.

5. Menentukan tingkat kesehatan perusahaan ditinjau dari segi karyawannya.

6. Menentukan besarnya pajak yang dibebankan perusahaan kepada pemerintah atau menentukan tingkat keuntungan yang wajar suatu industri.

7. Menentukan tingkat perkembangan perusahaan untuk kepentingan evaluasi.

8. Menentukan tingkat kekuatan keuangan pesaing/kompetitor (positioning).

9. Menentukan besarnya tingkat kerusakan yang dihadapi perusahaan.

\subsubsection{Jenis-jenis Rasio Keuangan}

\subsubsection{Rasio Likuiditas}

Menurut Hanafi dan Halim (2016:75), rasio likuiditas adalah "rasio yang mengukur kemampuan likuiditas jangka pendek perusahaan dengan melihat aktiva lancar 
perusahaan relatif terhadap utang lancarnya (utang dalam hal ini adalah kewajiban perusahaan)." Meskipun rasio ini tidak bicara masalah solvabilitas (kewajiban jangka panjang), dan biasanya relatif tidak penting dibandingkan rasio solvabilitas, tetapi rasio likuiditas yang jelek dalam jangka panjang juga akan mempengaruhi solvabilitas perusahaan. Dua rasio likuiditas jangka pendek yang sering digunakan adalah rasio lancar dan rasio quick (acid test ratio).

Menurut Raharjaputra (2009:199) rasio likuiditas ini sebenarnya paling banyak mendapat perhatian dari para analisis mampu investor. Walaupun analisis terhadap likuiditas ini membutuhkan bantuan lain, namun penggunaan rasio ini terbilang cepat dan mudah. Adapun tujuan dan manfaat rasio likuiditas ;

1. Untuk mengukur kemampuan perusahaan membayar kewajiban atau utang yang segera jatuh tempo pada saat ditagih. Artinya, kemampuan untuk membayar kewajiban yang sudah waktunya dibayar sesuai jadwal batas waktu yang telah ditetapkan.

2. Untuk mengukur kemampuan perusahaan membayar kewajiban jangka pendek dengan aktiva secara keseluruhan. Artinya, jumlah kewajiban yang berumur di bawah satu tahun atau sama dengan satu dengan satu tahun dibandingkan dengan total aktiva lancar.

3. Untuk mengukur kemampuan perusahaan membayar kewajiban jangka pendek dengan aktiva lancar tanpa memperhitungkan sediaan atau piutang, dalam hal ini aktiva lancar dikurangi sediaan dan utang yang dianggap likuiditasnya lebih rendah.

4. Untuk mengukur atau membandingkan antara jumlah sediaan yang ada dengan modal kerja perusahaan.

5. Untuk mengukur seberapa besar uang kas yang tersedia untuk membayar utang. Sedangkan alat perencanaan ke depan, terutama yang berkaitan dengan perencanaan kas dan utang.

6. Untuk melihat kondisi dan posisi likuiditas perusahaan dari waktu ke waktu dengan membandingkan untuk beberapa periode.

7. Untuk melihat kelemahan yang dimiliki perusahaan, dari masing-masing komponen yang ada di aktiva lancar dan utang lancar. 
8. Menjadi alat pemicu bagi pihak manajemen untuk memperbaiki kinerjanya, dengan melihat rasio likuiditas yang ada pada saat ini.

Adapun jenis rasio likuditas yang dianalisis meliputi ;

1. Current ratio (rasio lancar)

Aktiva lancar menggambarkan alat bayar dan diasumsikan semua aktiva lancar benar-benar bisa digunakan untuk membayar. Sedangkan utang lancar menggambarkan yang harus dibayar dan diasumsikan semua utang lancar benarbenar dibayar. Current ratio sangat berguna untuk mengukur likuiditas perusahaan, akan tetapi dapat menjebak.

Hal ini dikarenakan current ratio yang tertinggi dapat disebabkan oleh adanya piutang yang tidak tertagih atau persediaan yang tidak terjual, yang tentu saja tidak dapat dipakai untuk membayar utang. Untuk menguji apakah alat bayar tersebut benar-benar likuid (benar-benar dapat digunakan untuk membayar utangnya), maka alat bayar yang kurang atau tidak likuid harus dikeluarkan dari total aktiva lancar. Alat bayar yang kurang likuid ini misalnya persediaan dan pos-pos yang analog dengan persediaan (Dwi dan Rifka. 2008:85).

Rasio yang menunjukkan adanya kelebihan aktiva lancar, yang akan mempunyai pengaruh yang tidak baik menghasilkan terhadap profitabilitas perusahaan. Aktiva lancar secara umum menghasilkan return yang lebih rendah dibandingkan dengan aktiva tetap. Rasio ini dapat dihitung dengan rumus:

Current Ratio $=\frac{\text { Aktiva Lancar }}{\text { Hitung Lancar }}$

Aktiva lancar (current assets) merupakan harta perusahaan yang dapat dijadikan uang dalam waktu singkat (maksimal satu tahun). Komponen aktiva lancar meliputi kas, bank, surat-surat berharga, piutang, sediaan, biaya dibayar dimuka, pendapatan yang masih harus diterima, pinjaman yang diberikan dan aktiva lancar lainnya.

Hutang lancar (current liabilities) merupakan kewajiban perusahaan jangka pendek (maksimal satu tahun). Artinya, utang ini segera harus dilunasi dalam waktu paling lama satu tahun. Komponen utang lancar terdiri dari utang dagang, utang bank atau tahun, utang wesel, utang gajih, utang pajak, utang dividen, biaya diterima 
dimuka, utang jangka panjang yang sudah hampir jatuh tempo, serta utang jangka pendek lainnya. Rumus current ratio menurut Sugiono dan Untung (2016):

$$
\text { Current Ratio }=\frac{\text { Aktiva Lancar }}{\text { Hitung Lancar }} \times 100 \%
$$

Pada kenyataannya, current ratio yang terlalu tinggi juga dianggap tidak baik. Fahmi (2011) menyebutkan terdapat indikasi masalah dari nilai current ratio yang ekstrim, antara lain;
a. Penimbunan kas,
b. Banyaknya piutang yang tidak tertagih.
c. Penumpukan persediaan.
d. Tidak efisiensinya pemanfaatan pembiayaan gratis dari pemasok.
e. Rendahnya pinjaman jangka pendek.

Meski memang nilai current ratio yang relatif rendah akan meningkatkan kekhawatiran yang lebih besar, tetapi dapat menjadi ukuran kinerja manajemen perusahaan telah berjalan secara efektif.

\section{Quick Ratio}

Menurut Sunyoto (2013: 90) quick ratio adalah "rasio hasil perbandingan antara kas dan aktiva lancar (quick assets) dengan utang lancar atau utang jangka pendek. Rumus quick ratio menurut Sugiono dan Untung (2016:58) ;

$$
\text { Quick Ratio }=\frac{\text { Total Aktiva Lancar }- \text { Persediaan }}{\text { Total Kewajiban Lancar }} \times 100 \%
$$

\section{Cash Ratio}

Menurut Sugiono (2016:58) bahwa "kas ratio merupakan perbandingan antara kas yang ada di perusahaan di bank (termasuk surat berharga seperti deposito) dibandingkan dengan total hutang lancar." Sedangkan menurut Sunyoto (2013:91) cash ratio menunjukkan kemampuan perusahaan dalam memenuhi kewajiban jangka pendeknya dengan uang kas dan surat berharga yang mudah diperdagangkan, yang tersedia di dalam perusahaan. Rumus cash ratio menurut Sugiono dan Untung (2016:58):

$$
\text { Cash Ratio }=\frac{\text { Kas }}{\text { Total Kewajiban Lancar }} \times 100 \%
$$




\subsubsection{Rasio Solvabilitas}

Menurut Weston (Kasmir, 2016: 150), "rasio solvabilitas merupakan rasio yang digunakan untuk mengukur sejauh mana aktiva perusahaan dibiayai dengan utang dan untuk mengukur kemampuan perusahaan dalam membayar seluruh kewajibannya, baik jangka pendek maupun jangka panjang apabila perusahaan dilikidasi (dibubarkan). Rasio yang digunakan meliputi:

1. Rasio Hutang Terhadap Aktiva (Total Debt to Asset Ratio)

Rasio ini mengukur seberapa besar aktiva perusahaan yang dibiayai oleh utang atau seberapa besar hutang perusahaan dapat berpengaruh terhadap pengelolaan aktiva. Rumusnya adalah ;

Debt to Assets Ratio $=\frac{\text { Total Hutang }}{\text { Modal Aktiva }} \times 100 \%$

2. Rasio Hutang Terhadap Ekuitas (Total Debt to Equity Ratio)

Rasio ini akan menunjukkan hubungan antara jumlah utang jangka panjang dengan jumlah modal sendiri yang diberikan oleh pemilik perusahaan, untuk mengetahui jumlah dana yang disediakan kreditor dengan pemilik perusahaan.

Debt to Equity Ratio $=\frac{\text { Total Hutang }}{\text { Modal Sendiri }} \times 100 \%$

Adapun tujuan dan manfaat rasio solvabilitas, yaitu:

a. Menganalisis status perusahaan dan kemampuannya dalam memenuhi kewajibannya pada pihak ketiga.

b. Mengetahui status perusahaan dengan melihat keseimbangan antara jumlah modal dan aktiva tetap yang dimiliki.

c. Mencari tahu berapa besarnya rupiah dari modal sendiri yang akan digunakan sebagai jaminan pembayaran utang jangka panjang.

d. Untuk melihat sejauhmana pengaruh utang yang ditanggung perusahaan terhadap pengelolaan aktiva yang ada.

Seberapa banyak aset atau aktiva yang dimilki oleh perusahaan dapat mencerminkan kondisi operasional perusahaan. Semakin banyak aktiva yang 
dimilikinya maka semakin tinggi kemampuan perusahaan tersebut dalam melunasi utang yang dimilikinya. Sebaliknya, jumlah aktiva yang sedikit akan menyusahkan perusahaan dalam melunasi utang-utang yang ditanggungnya. Rasio solvabilitas biasanya diperlukan ketika perusahaan akan tutup untuk memastikan bahwa ia bisa melunasi utang-utangnya atau tidak.

\subsubsection{Rasio Profitabilitas}

Menurut Sunyoto (2013:113), pengertian rasio profitabilitas adalah kemampuan perusahaan untuk memperoleh keuntungan dari usahanya. Menurut Sugiono dan Untung (2016: 66), rasio profitabilitas bertujuan untuk mengukur efektifitas manajemen yang tercermin pada imbalan atas hasil investasi melalui kegiatan perusahaan atau mengukur kinerja perusahaan secara keseluruhan dan efisiensi dalam pengelolaan kewajiban dan modal.

Rasio ini memiliki beberapa tujuan dan manfaat menurut Kasmir (2016), antara lain ;

1. Untuk mengukur atau menghitung laba yang diperoleh perusahaan dalam satu periode tertentu.

2. Untuk menilai posisi laba perusahaan tahun sebelumnya dengan tahun sekarang.

3. Untuk mengetahui perkembangan laba dari waktu ke waktu.

4. Untuk menilai besarnya laba bersih sesudah pajak dengan modal sendiri.

Rasio profitabilitas terdiri dari beberapa jenis. Berbagai jenis ini menilai dengan ukuran yang berbeda untuk menghasilkan informasi mengenai kemampuan perusahaan dalam menghasilkan profit. Jenis-jenis tersebut antara lain:

\section{Gross Profit Margin}

Home dan Wachowiccz (2012) menjelaskan bahwa rasio ini memberi tahu kita laba dari perusahaan yang berhubungan dengan penjualan setelah kita mengurangi biaya untuk memproduksi barang yang dijual. Menurut Sugiono dan Untung (2016: 66) menjelaskan bahwa rasio ini menunjukkan harga besar keuntungan kotor yang dijual dari menjual produk.

$$
\text { Gross Profit Margin }=\frac{\text { Laba Kotor }}{\text { Penjualan }} \times 100 \%
$$




\section{Net Profit Margin}

Menurut Sugiono dan Untung (2016: 67) mengemukakan bahwa "rasio ini menunjukkan berapa besar keuntungan bersih yang diperoleh perusahaan. Jika Net profit margin suatu perusahaan lebih rendah dari rata-rata industrinya, maka hal ini dapat disebabkan oleh harga pokok penjualan lebih tinggi dari perusahaan pesaing atau kedua-duanya."

Net Profit Margin $=\frac{\text { Laba Bersih }}{\text { Penjualan Bersih }} \times 100 \%$

Besarnya persentase keuntungan baik laba kotor maupun laba bersih bergantung pada jenis usaha perusahaan, untuk perdagangan biasanya mempunyai persentase laba lebih kecil dibandingkan dengan persentase laba perusahaan manufaktur. Hal ini disebabkan faktor resiko, di mana perusahaan perdagangan mempunyai resiko lebih kecil dibandingkan dengan perusahaan manufaktur.

\section{Return on Asset}

Danuarta (2014) mengatakan bahwa return on asset adalah kemampuan suatu perusahaan dengan seluruh modal yang bekerja di dalamnya untuk menghasilkan laba operasi perusahaan atau laba sebelum bunga dan pajak.

Return on Asset $=\frac{\text { Laba Bersih }}{\text { Total Aktiva }} \times 100 \%$

Presentase rendah sebagai hasil dari perhitungan ini memberikan informasi bahwa kurangnya kinerja perusahaan dari segi pemanfaatan aset untuk menghasilkan laba. Langkah yang dapat diambil oleh perusahaan untuk meningkatkan persentase ini salah satunya dengan meningkatkan pendapatan atau menekan biaya-biaya operasi.

\section{Return on Equity}

Menurut Sugiono dan Untung (2016: 68) rasio ini mengukur tingkat pengembalian dari bisnis atas seluruh modal yang ada. ROE merupakan slaah satu indikator yang digunakan pemegang saham untuk mengukur keberhasilan bisnis yang dijalani. Rasio ini dapat disebut juga dengan rentabilitas modal sendiri.

$$
\text { Return on Equity }=\frac{\text { Laba Bersih }}{\text { Total Ekuitas }} \times 100 \%
$$


Return on Equity yang tinggi sering kali mencerminkan penerimaan perusahaan atas peluang investasi yang baik dan manajemen biaya yang efektif. Semakin tingginya presentase dari rasio ini juga memberikan manfaat berupa semakin kuatnya posisi pemilik modal perusahaan.

\subsection{Kerangka Pikir}

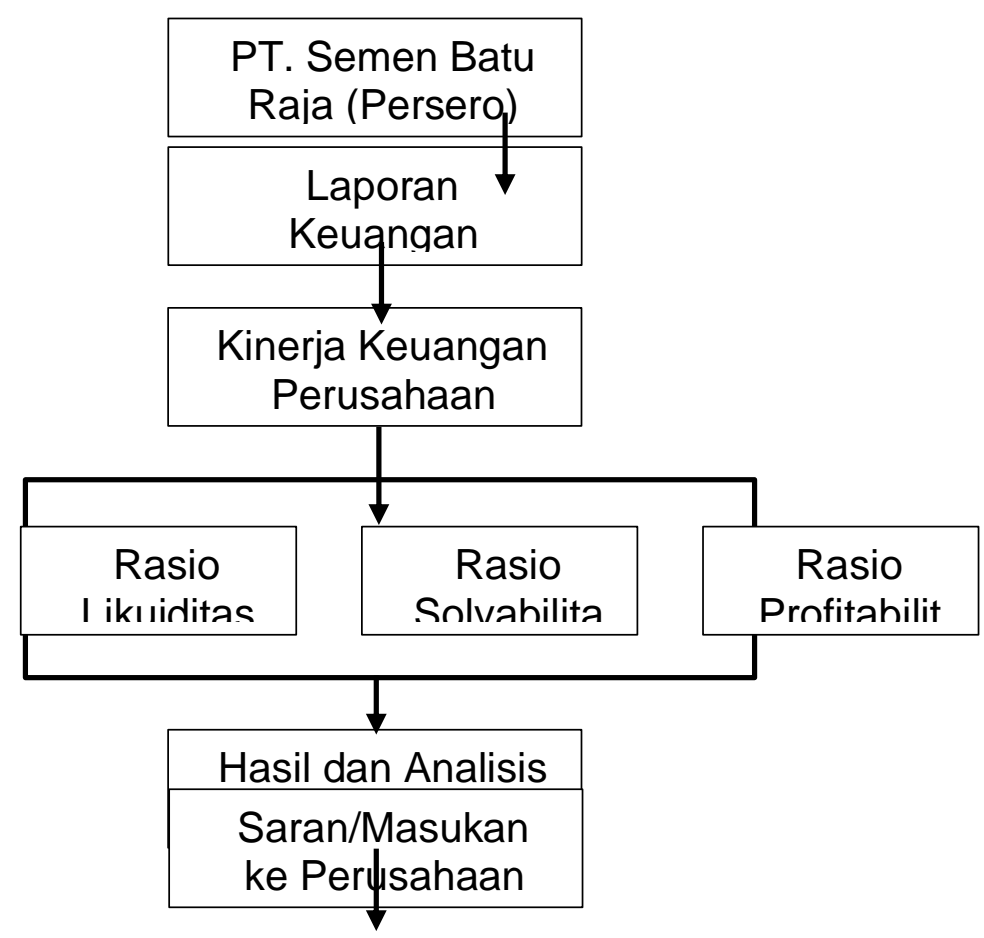

Gambar 1. Skema Kerangka Pikir 


\section{METODE PENELITIAN}

\section{A. Lokasi dan Waktu penelitian}

Lokasi dan waktu penelitian ini dilakukan pada perusahaan PT. Semen Batu Raja (Persero) Tbk Di Kota Makassar Dengan waktu penelitian selama 1 bulan

\section{B. Jenis dan sumber data}

Jenis data yang digunakan dalam penelitian ini adalah data sekunder yang sumber datanya diperoleh dari Bursa Efek Indonesia.

\section{Populasi dan sampel}

1. Poulasi dalam penelitian ini adalah perusahaan yang terdapat di Bursa Efek Indonesia ( BEI ) yang selalu menyajikan laporan keuangan selama tahun 2016-2019.

2. Adapun sampel dalam penelitian ini adalah terdapat di laporan keuangan di Bursa Efek Indonesia (BEI).

\section{Tekni Pengumpulan Data}

Sesuai dengan jenis data yang diperlukan yaitu data sekunder maka pengumpulan didasarkan pada laporan keuangan yang dipublishkan di Bursa Efek Indonesia.

\section{E. Teknik Analisis Data}

\section{A. Likuiditas}

1. Current ratio (Rasio lancar)

$$
\text { Current Ratio }=\frac{\text { Aktiva Lancar }}{\text { Hitung Lancar }} \times 100 \%
$$

2. Quick ratio (Rasio cepat)

$$
\text { Quick Ratio }=\frac{\text { Total Aktiva Lancar }- \text { Persediaan }}{\text { Total Kewajiban Lancar }} \times 100 \%
$$

3. Cash ratio (Rasio kas) 


$$
\text { Cash Ratio }=\frac{\text { Kas }}{\text { Total Kewajiban Lancar }} \times 100 \%
$$

\section{B. Solvabilitas}

1. Rasio Hutang Terhadap Aktiva (Total Debt to Asset Ratio)

Debt to Assets Ratio $=\frac{\text { Total Hutang }}{\text { Modal Aktiva }} \times 100 \%$

2. Rasio Hutang Terhadap Ekuitas (Total Debt to Equity Ratio)

Debt to Equity Ratio $=\frac{\text { Total Hutang }}{\text { Modal Sendiri }} \times 100 \%$

\section{Profitabilitas}

1. Gross Profit Margin

$$
\text { Gross Profit Margin }=\frac{\text { Laba Kotor }}{\text { Penjualan }} \times 100 \%
$$

\section{Net Profit Margin}

$$
\text { Net Profit Margin }=\frac{\text { Laba Bersih }}{\text { Penjualan Bersih }} \times 100 \%
$$

\section{Return on Asset}

$$
\text { Return on Asset }=\frac{\text { Laba Bersih }}{\text { Total Aktiva }} \times 100 \%
$$

4. Return on Equity

$$
\text { Return on Equity }=\frac{\text { Laba Bersih }}{\text { Total Ekuitas }} \times 100 \%
$$

\section{KESIMPULAN :}

Berdasarkan hasil penelitian dan pembahasan yang telah disajikan pada bab-bab sebelumnya, maka dapat diambil kesimpulan sebagai berikut :

Kinerja perusahaan merupakan suatu gambaran tentang kondisi keuangan suatu perusahaan yang dianalisis dengan alat-alat analisis keuangan, sehingga dapat 
diketahui mengenai baik buruknya keadaan keuangan suatu perusahaan yang mencerminkan prestasi kerja dalam periode tertentu.

\section{DAFTAR PUSTAKA}

Daga, R. (2016). EFEKTIVITAS KEMITRAAN PT. PLN (Persero) RANTING RAPPANG DENGAN KUD DALAM PENAGIHAN REKENING LISTRIK. AKMEN Jurnal IImiah, 13(4).

Munawir. (2000). Analisis Laporan Keuangan. Yogyakarta: Liberty.

Wild, J., Subramanyam, K., \& Halsey, R. (2005). Analisis Laporan Keuangan. Edisi Delapan, Buku Kesatu. Jakarta: Salemba Empat. 